$\begin{array}{ll}\text { Abstracta Iranica } & \begin{array}{l}\text { Abstracta Iranica } \\ \text { Revue bibliographique pour le domaine irano-aryen }\end{array} \\ & \text { Volume } 25 \mid \mathbf{2 0 0 4} \\ & \text { Comptes rendus des publications de } \mathbf{2 0 0 2}\end{array}$

\title{
« Une amulette du Museum für Islamische Kunst de Berlin ».JSAI, 26, 2002, pp. 176-186.
}

\section{Rika Gyselen}

\section{(2) OpenEdition}

Édition électronique

URL : http://journals.openedition.org/abstractairanica/4489

ISSN : 1961-960X

\section{Éditeur :}

CNRS (UMR 7528 Mondes iraniens et indiens), Éditions de l'IFRI

Édition imprimée

Date de publication : 15 mai 2004

ISSN : 0240-8910

\section{Référence électronique}

Rika Gyselen, « « Une amulette du Museum für Islamische Kunst de Berlin ». JSAI, 26, 2002, pp.

176-186. », Abstracta Iranica [En ligne], Volume 25 | 2004, document 131, mis en ligne le 15 mars 2006, consulté le 25 septembre 2020. URL : http://journals.openedition.org/abstractairanica/4489

Ce document a été généré automatiquement le 25 septembre 2020.

Tous droits réservés 
« Une amulette du Museum für Islamische Kunst de Berlin ». JSAI, 26, 2002, pp. 176-186.

\section{Rika Gyselen}

1 Tentative de déchiffrement d'une inscription sur un sceau magique conservé dans les collections du Musée de l'art islamique de Berlin. Le sceau comporte deux faces gravées ainsi qu'une tranche. Sur chaque côté figure un motif iconographique d'un type connu par d'autres sceaux magiques lesquels portent également des inscriptions non déchiffrées jusqu'à présent. Le texte se compose d'une part d'une "lettre", un genre littéraire qu'on retrouve sur d'autres obj ets à caractère magique, et d'autre part, d'une incantation.

\section{INDEX}

Thèmes : 4.1. Histoire médiévale

\section{AUTEURS}

RIKA GYSELEN

CNRS - Paris 